Bedankt voor het downloaden van dit artikel. De artikelen uit de (online)tijdschriften van Uitgeverij Boom zijn auteursrechtelijk beschermd. U kunt er natuurlijk uit citeren (voorzien van een bronvermelding) maar voor reproductie in welke vorm dan ook moet toestemming aan de uitgever worden gevraagd.

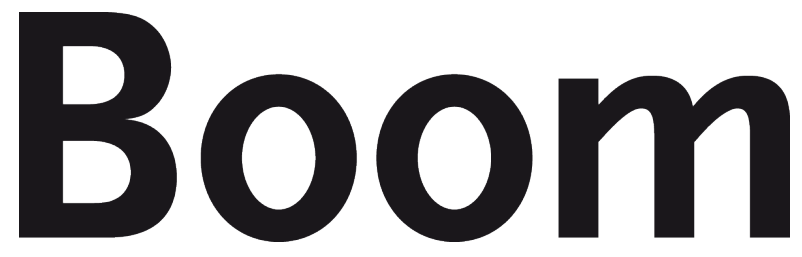

Behoudens de in of krachtens de Auteurswet van 1912 gestelde uitzonderingen mag niets uit deze uitgave worden verveelvoudigd, opgeslagen in een geautomatiseerd gegevensbestand, of openbaar gemaakt, in enige vorm of op enige wijze, hetzij elektronisch, mechanisch door fotokopieën, opnamen of enig andere manier, zonder voorafgaande schriftelijke toestemming van de uitgever.

Voor zover het maken van kopieën uit deze uitgave is toegestaan op grond van artikelen $16 \mathrm{~h} \mathrm{t} / \mathrm{m} \mathrm{16m}$ Auteurswet 1912 jo. Besluit van 27 november 2002, Stb 575, dient men de daarvoor wettelijk verschuldigde vergoeding te voldoen aan de Stichting Reprorecht te Hoofddorp (postbus 3060, 2130 KB, www.reprorecht.nl) of contact op te nemen met de uitgever voor het treffen van een rechtstreekse regeling in de zin van art. 16l, vijfde lid, Auteurswet 1912.

Voor het overnemen van gedeelte(n) uit deze uitgave in bloemlezingen, readers en andere compilatiewerken (artikel 16, Auteurswet 1912) kan men zich wenden tot de Stichting PRO (Stichting Publicatie- en Reproductierechten, postbus 3060, 2130 KB Hoofddorp, www.cedar.nl/pro).

No part of this book may be reproduced in any way whatsoever without the written permission of the publisher.

info@boomamsterdam.nl www.boomuitgeversamsterdam.nl 


\title{
ARTIKELEN
}

\section{De werk-privébalans van zelfstandig ondernemers}

\author{
Anne Annink \& Laura den Dulk*
}

Het doel van dit artikel is om een overzicht te geven van wat we tot nu toe weten over de ervaren werk-privébalans van verschillende typen zelfstandig ondernemers in verschillende landen. De bevindingen in dit artikel zijn grotendeels gebaseerd op een proefschrift met zes afzonderlijke, recent gepubliceerde studies die allemaal een landenvergelijkend-onderzoek-ontwerp hebben. Deze zes studies bestaan uit een literatuurstudie, een overzichtsstudie van de overheidssteun in Europese landen voor de werk-privébalans van ondernemers, een drietal kwantitatieve, empirische studies op basis van de European Social Survey (2004 en 2010) en de Global Entrepreneurship Monitor (2013) en een kwalitatieve-interview-studie (2016) onder vijftig zelfstandige professionals in drie landen (Nederland, Spanje en Zweden) (Annink, 2017). De bevindingen laten zien dat het van belang is om de heterogeniteit van zelfstandig ondernemers in ogenschouw te nemen. Kenmerken van het werk en het bedrijf beïnvloeden de ervaren werk-privébalans. In het bijzonder noodgedwongen ondernemerschap en veel contact met klanten beïnvloeden de balans negatief. Ook het beleid, de economische situatie en culturele aspecten in een land hebben invloed op de ervaren werkprivébalans van zelfstandig ondernemers.

\section{Inleiding}

Dit artikel gaat in op ervaringen van zelfstandig ondernemers met de combinatie van betaald werk en andere levensdomeinen. Het is van belang om naar de werkprivé-ervaringen van zelfstandig ondernemers te kijken, niet alleen omdat hun ervaringen van die van werknemers in loondienst kunnen verschillen, maar ook omdat spanningen of conflict tussen levensdomeinen van invloed zijn op de gezondheid, het welbevinden van deze groep werkenden, alsook het economisch succes van ondernemerschap (OECD, 2011; Williams, 2004). Onderzoek naar de werk-privébalans heeft zich tot nog toe, op enkele uitzonderingen na, (Johansson Sevä \& Öun, 2015; Nordenmark et al., 2012; Prottas \& Thompson, 2006) vooral gericht op werknemers werkzaam bij grote organisaties (Den Dulk \& Peper, 2009).

Het is onwaarschijnlijk dat onderzoeksbevindingen van werknemers in loondienst zonder meer gegeneraliseerd kunnen worden naar zelfstandig ondernemers. Hun werksituatie verschilt in veel opzichten van die van werknemers: ze werken in het algemeen langer en meer onregelmatige uren, ze hebben meer flexibiliteit

* Anne Annink is werkzaam bij Leyden Academy. E-mailadres: mail@anneannink.nl. Laura den Dulk is werkzaam aan de Erasmus Universiteit Rotterdam, afdeling Bestuurskunde en sociologie. 
en autonomie in hun werk (kunnen veelal zelf bepalen wanneer, waar en hoe ze hun werk doen), en rapporteren meer werkonzekerheid en minder sociale steun dan werknemers (Taris et al., 2008; Tuttle \& Garr, 2009). Daarnaast hebben zelfstandig ondernemers minder toegang tot sociale zekerheid (Annink et al., 2016a) en het arbeid- en zorgbeleid ter ondersteuning van de combinatie werk en gezin (Annink et al., 2015; Yerkes \& Den Dulk, 2015). Ondanks het gegeven dat onderzoek laat zien dat zelfstandig ondernemers conflict kunnen ervaren bij het combineren van verschillende levensdomeinen blijven zij ondervertegenwoordigd in onderzoek op dit terrein. Vooralsnog is het onduidelijk hoe verschillende typen zelfstandig ondernemers hun werk-privébalans ervaren, welke factoren van invloed zijn, en welke vorm van steun het meest passend is.

In dit artikel staat de volgende vraag centraal: 'Welke factoren zijn van invloed op de ervaren werk-privébalans van verschillende typen zelfstandig ondernemers?' Deze vraag wordt beantwoord aan de hand van drie deelvragen: (a) 'Hoe ervaren verschillende typen zelfstandig ondernemers hun werk-privébalans in vergelijking met werknemers in loondienst?', (b) 'Hoe beïnvloeden kenmerken van het werk de werk-privébalans van zelfstandig ondernemers?', en (c) 'Hoe wordt de werkprivébalans van zelfstandig ondernemers gevormd door de nationale context?'

'Balans' verwijst in dit artikel naar de tevredenheid met het combineren van werk en andere levensdomeinen (bijv. Valcour, 2007; Voydanoff, 2005). 'Werk' verwijst dan naar betaalde arbeid, terwijl 'privé' verwijst naar activiteiten daarbuiten, zoals gezondheid, zorgtaken, ontspanning, vrienden en familie (Guest, 2002). Werk-privébalans wordt in de literatuur op verschillende manieren geoperationaliseerd en gerelateerd aan andere concepten. De studies waarnaar in dit artikel wordt verwezen, sluiten zoveel mogelijk aan bij de bestaande literatuur. In de bestaande literatuur wordt werk-privébalans omschreven als de afwezigheid van conflict tussen werk en gezin, de algemene tevredenheid waarop men succesvol taken en doelen in werk en privéleven kan combineren, subjectief welzijn en mogelijkheden voor werk-privébalans (Annink, 2017). Werk-privébalans is een belangrijke indicator voor de individuele gezondheid, het welzijn en de prestaties in het werk. Daarnaast heeft de werk-privébalans niet alleen invloed op de zelfstandig ondernemer, maar ook op zijn of haar vrienden, familie en andere sociale contacten (Allen et al., 2000; Gorgievski et al., 2010; Shelton, 2006; Williams, 2004).

Een belangrijke bijdrage van dit artikel is het onderscheid dat gemaakt wordt tussen verschillende typen zelfstandig ondernemers. Vanwege de flexibilisering van de arbeidsmarkt ontstaan er nieuwe categorieën van zelfstandig ondernemerschap die vallen tussen werknemers in loondienst en de traditionele zelfstandigen (zoals boeren en freelancers) (Casale, 2011; Kremer et al., 2017). In bestaand onderzoek worden typen ondernemers onderscheiden op basis van gedragskenmerken (zoals motivatie) en wettelijke bepalingen (zoals de rechtsvorm en gerelateerde belastingmaatregelen). In verschillende landen worden verschillende termen gebruikt om legale categorieën van zelfstandig ondernemerschap te duiden. Zelfstandig ondernemer en zzp'er (zelfstandige zonder personeel) worden bijvoorbeeld beide gebruikt om werkenden te definiëren die werken voor eigen 
rekening en risico, of die worden bijgestaan door werknemers of door onbetaalde familieleden (Stephan \& Roesler, 2010). Zzp'ers worden internationaal gezien ook gedefinieerd als 'nano-businesses', 'sole traders', 'own account workers', 'freelancers' en 'independent contractors' (McKeown, 2015). Naast gedragskenmerken en wettelijke bepalingen onderscheidt dit artikel ook typen ondernemers op basis van werk- en bedrijfskenmerken. Dit maakt het mogelijk om de verschillende ervaringen van zelfstandig ondernemers gedetailleerder te bestuderen en nuances aan te brengen in huidig onderzoek dat voornamelijk zelfstandig ondernemers afzet tegen werkenden in loondienst.

Naast kenmerken van het werk kan ook de nationale context werk-privé ervaringen beïnvloeden. Zelfstandig ondernemers worden beschouwd als onafhankelijk en autonoom en de werk-privébalans als een individuele ervaring. De werk-privébalans is echter een product van de relatie tussen de zelfstandige als een persoon en zijn of haar sociale en fysieke omgeving. Door een landenvergelijkend perspectief kan inzicht worden verkregen in de invloed van de beleidscontext, de economische situatie en de culturele context op de ervaren werk-privébalans van zelfstandigen. De bevindingen in dit artikel zijn grotendeels gebaseerd op een proefschrift met zes afzonderlijke, recent gepubliceerde studies die allemaal een landenvergelijkend-onderzoek-ontwerp hebben. Deze zes studies bestaan uit een literatuurstudie, een overzichtsstudie van de overheidssteun in Europese landen voor de werk-privébalans van ondernemers, een drietal kwantitatieve, empirische studies op basis van de European Social Survey (2004 en 2010) en de Global Entrepreneurship Monitor (2013), en een kwalitatieve-interview-studie (2016) onder vijftig zelfstandige professionals in drie landen (Nederland, Spanje en Zweden) (Annink, 2017). Alvorens de bevindingen te bespreken wordt eerst ingegaan op de theoretische invalshoek en de methoden van onderzoek in de zes studies. Daarna worden de drie deelvragen besproken die samen het antwoord op de hoofdvraag geven. Dit artikel eindigt met aanbevelingen voor wetenschap en de praktijk.

\section{Theorie en methoden van onderzoek}

De meest prominente benadering om de werk-privébalans van werknemers en zelfstandig ondernemers te verklaren is het 'Job Demands and Resources Model' (JDR-model) (Bakker \& Demerouti, 2007; Davis et al., 2014; Demerouti et al., 2001; Nordenmark et al., 2012). De basis aanname van dit model is dat taakeisen zoals werktijden, overwerk en zorgtaken, in de verschillende levensdomeinen niet altijd makkelijk te combineren zijn en kunnen leiden tot werk-privéconflict. Kenmerkend voor taakeisen is dat ze tijd en energie kosten. Aan de andere kant kunnen hulpbronnen helpen bij het vinden van een balans (Bakker \& Demerouti, 2007; Bianchi \& Milkie, 2010; Voydanoff, 2005). Op basis van het JDR-model lijkt zelfstandig ondernemen een goede strategie om meer autonomie te creëren in relatie tot de werk-privébalans in vergelijking tot het werken in loondienst (Johansson Sevä \& Öun, 2015; Gimenez-Nadal \& Sevilla, 2012). Met name flexibiliteit en controle over het werk worden geassocieerd met een hogere tevredenheid met de werk-privébalans (Davis et al., 2014). Dankzij autonomie kunnen 
zelfstandig ondernemende ouders bijvoorbeeld (een deel van) hun betaalde werk naar de avond verschuiven wanneer de partner voor de kinderen kan zorgen (Gimenez-Nadal \& Sevilla, 2012). Daarnaast zijn zelfstandig ondernemers vrij van opgelegde normen, waarden en verwachtingen over hoe het werk wordt gedaan binnen een organisatie. De cultuur op de werkplek en leidinggevenden kunnen belemmeringen creëren om een werk-privébalans te realiseren door uit te gaan van een ideale werker die altijd beschikbaar is, fulltime werkt en geen verplichtingen of verantwoordelijkheden heeft naast het werk (Den Dulk et al., 2016; Lewis et al., 2009). Aan de andere kant zijn er auteurs die op basis van het JDR-model beargumenteren dat het lastiger is voor zelfstandigen om werk en privé te combineren omdat zij te maken hebben met hogere taakeisen dan werknemers in loondienst, zoals langere werkuren, werkonzekerheid en minder sociale steun op het werk (Taris et al., 2008; Tuttle \& Garr, 2009). Uit onderzoek onder werknemers is gebleken dat hogere taakeisen de kans op werk-privéconflict vergroten (Greenhaus \& Beutell, 1985; Grzywacz \& Marks, 2000; Frone, 2003). Op basis van recent onderzoek kan echter ook beargumenteerd worden dat sommige taakeisen ook een positief effect kunnen hebben op de werk-privébalans als ze als uitdagend worden ervaren en verbonden zijn met positieve effecten zoals het creëren van een succesvol bedrijf (Wood \& Michealides, 2015).

Het JDR-model kijkt vooral naar baankenmerken, en het heuristische karakter van het model maakt het mogelijk om de invloed van verschillende taakeisen en hulpbronnen te toetsen in verschillende werkcontexten (Schaufeli \& Taris, 2014). In bestaand onderzoek wordt echter weinig gekeken naar specifieke werken bedrijfskenmerken van zelfstandig ondernemers en in hoeverre deze als een taakeis of hulpbron worden ervaren in relatie tot de werk-privébalans. Daarnaast besteedt het JDR-model weinig aandacht aan de sociale en institutionele context zoals de beleidscontext of de economische en culturele context waarin mensen werk en privéleven combineren (Den Dulk et al., 2011).

Alle zes de afzonderlijke, eerder gepubliceerde studies hebben een landenvergelijkend-onderzoek-ontwerp om zo de invloed van de nationale context op de ervaren werk-privébalans te kunnen onderzoeken. De eerste studie is een systematische literatuurstudie die de huidige stand van onderzoek naar de werk-privébalans van zelfstandig ondernemers in kaart brengt (Annink, 2017). De tweede studie geeft een overzicht van overheidssteun voor de werk-privébalans van zelfstandig ondernemers in Europese landen (Annink et al., 2015). De derde studie is een empirische studie op basis van de European Social Survey (2010) en vergelijkt het ervaren werk-privéconflict tussen werknemers en zelfstandig ondernemers en de rol van overheidsbeleid (Annink et al., 2016b). De vierde studie richt zich op verschillende typen ondernemers en verkent de relatie tussen specifieke kenmerken van het werk van zelfstandig ondernemers (klantgerichtheid, innovatie, aantal werknemers, motivatie en bedrijfsfase) en tevredenheid met de werk-privébalans (Annink et al., 2016c). Het doel van deze studie is om te toetsen of kenmerken gerelateerd aan het bedrijf van zelfstandigen worden ervaren als taakeisen en/of als een hulpbron. Deze studie maakt gebruik van de Global Entrepreneurship Monitor (2013). De vijfde studie toetst de relatie tussen financiële zorgen en subjectief welzijn op basis van de European Social Survey 
(2004 en 2010) en maakt daarbij gebruik van data van 9.755 zelfstandig ondernemers uit 31 Europese landen (Annink et al., 2016a). Om beter zicht te krijgen op de rol van de sociale en institutionele context wordt gebruikgemaakt van de 'Conservation of Resources Theory'. De 'Conservation of Resources Theory' stelt dat mensen ernaar streven om hun hulpbronnen te bewaken of (opnieuw) te verkrijgen (Hobfoll, 1989, 2001). Verlies van hulpbronnen resulteert in verder verlies, met een neerwaartse spiraal als gevolg (Hobfoll, 2001). Dit betekent dat zelfstandig ondernemers die zware taakeisen in één domein ervaren (zoals financiële tekorten), al hun energie nodig hebben om aan de aan hun werk gerelateerde verantwoordelijkheden te kunnen voldoen. Dit kan ten koste gaan van de energie voor andere levensdomeinen met stress, verminderd welzijn en werk-privébalans als gevolg. In deze studie werd naast de directe relatie tussen financiële zorgen en subjectief welzijn ook de indirecte (verzachtende) invloed van persoonlijke hulpbronnen (opleiding), sociale hulpbronnen (vertrouwen), culturele aspecten (het percentage zelfstandig ondernemers op de arbeidsmarkt) en institutionele aspecten (het werkloosheidspercentage in een land) beschouwd. Tot slot kijkt de zesde en laatste studie specifiek naar de rol van sociale steun. Deze studie is gebaseerd op interviews met vijftig zelfstandige professionals in drie landen (Nederland, Spanje en Zweden) (Annink, 2016). Zelfstandige professionals zijn de snelst groeiende groep op de Europese arbeidsmarkt (Leighton \& Brown, 2013). Deze zelfstandigen zijn hoogopgeleid en werken alleen, zonder steun van collega's of leidinggevende. Daarom wordt aangenomen dat sociale steun voor de werk-privébalans voor hen extra belangrijk is. De mate waarin sociale steun kan worden omgezet naar daadwerkelijke hulpbronnen voor de werk-privébalans, wordt in deze studie onderzocht met behulp van de capabilitiy-benadering van Sen (1985), zoals toegepast in Hobson (2011). De capability-benadering legt niet zozeer de nadruk op de keuzes die mensen maken met betrekking tot hun werk-privébalans maar wat voorafgaat aan deze keuzes: de mogelijkheden (capabilities) die daadwerkelijk binnen het bereik liggen van mensen om hun werk-privébalans vorm te geven (Yerkes \& Den Dulk, 2015). Deze benadering gaat ervan uit dat mensen niet altijd in staat zijn bestaande hulpbronnen in te zetten. Individuele, sociaal-culturele en institutionele factoren kunnen van invloed zijn op de omzetting van hulpbronnen in 'agency freedom' - de daadwerkelijke vrijheid en capaciteit om keuzes te maken (Hobson, 2014).

\section{Bevindingen}

A. De werk-privébalans van verschillende typen zelfstandig ondernemers in vergelijking met werknemers in loondienst

De eerste deelvraag heeft betrekking op de ervaren werk-privébalans van verschillende typen zelfstandig ondernemers in vergelijking met werkenden in loondienst. De literatuurstudie laat zien dat het merendeel van de bestaande kwantitatieve studies met een vergelijkend perspectief zich richten op de vraag in hoeverre zelfstandigen en werknemers werk-privéconflict ervaren (in het bijzonder de mate waarin werk conflicteert met gezinsverantwoordelijkheden thuis) (Annink et al., 2016b; Beutell et al., 2015; Brink \& De la Rey, 2001; Johansson Sevä \& Öun, 2015; König \& Cesinger, 2015; Parasuraman \& Simmers, 2001; Tremblay 
\& Genin, 2008). De onderzoeksresultaten zijn niet eenduidig. Hoewel het merendeel van de studies aangeeft dat zelfstandig ondernemers meer conflict ervaren dan werknemers, zijn er ook studies die geen verband vinden of een tegenovergesteld resultaat rapporteren. Studies die de tevredenheid met de werkprivébalans onderzoeken, rapporteren ook tegengestelde resultaten (Tuttle \& Garr, 2009; Jamal, 2009; Duncan \& Pettigrew, 2012; Nordenmark et al., 2012; Li et al., 2013; Davis et al., 2014).

Onderzoeksresultaten zijn lastig vergelijkbaar omdat gebruik wordt gemaakt van verschillende conceptualiseringen, meetinstrumenten, methoden en onderzoekspopulaties. Dat conceptualisering van belang is, blijkt bijvoorbeeld uit de studie van König en Cesinger (2015). Zij laten zien dat zelfstandig ondernemers iets minder tijd gerelateerd werk-privéconflict ervaren dan werkenden in loondienst, maar dat ze aan de andere kant meer spanningen ervaren (strain-based work-tofamily conflict). Een andere reden voor het gebrek aan eenduidige resultaten is dat weinig studies de heterogeniteit van zelfstandig ondernemers in beschouwing nemen. Slechts een paar studies richten zich specifiek op verschillende typen zelfstandigen en maken een vergelijking tussen ondernemers met en zonder personeel, mannelijke versus vrouwelijke ondernemers en wel/geen familiebedrijf. Zo laat onderzoek dat een vergelijking maakt tussen ondernemers met en zonder personeel zien dat ondernemers met personeel een groter risico lopen op werkprivéconflict (Bunk et al., 2012; Johansson Sevà \& Öun, 2015; Prottas \& Thompson, 2006). Vrouwelijke zelfstandigen die voor zichzelf werken zonder personeel, werken minder uren en ervaren minder conflict dan hun mannelijke collega's en ondernemers met personeel in dienst (Johansson Sevà \& Öun, 2015).

De kwalitatieve-interview-studie onder zelfstandige professionals (Annink, 2016) illustreert hoe een specifieke groep zelfstandigen haar werk-privébalans ervaart. Zelfstandige professionals zijn de snelst groeiende groep op de Europese arbeidsmarkt (Leighton \& Brown, 2013). Deze zelfstandigen zijn hoogopgeleid en werken alleen, zonder steun van collega's of leidinggevende. De meeste deelnemers aan deze studie waren zich bewust van het belang van werk-privébalans en de gevolgen daarvan, misschien omdat ze relatief hoogopgeleid zijn. In alle drie de landen (Nederland, Spanje en Zweden) waren de meeste zelfstandige professionals tevreden met de manier waarop hun verschillende levensdomeinen, zoals werk, familie, vrienden, zelf en (professionele) netwerkcontacten, overlappen (Annink, 2016). Echter, het merendeel van de deelnemers was niet tevreden met de tijdsverdeling in deze domeinen. In de meeste gevallen zouden zelfstandige professionals minder willen werken en meer tijd willen besteden aan persoonlijke levensdomeinen. Het is moeilijk voor hen om dit te realiseren omdat ze zich sterk identificeren met hun werk. Dit geldt voor vrijwel alle zelfstandige professionals in de drie landen. Het werk van deze zelfstandigen is vaak een uiting van persoonlijke interesses, ervaringen, vaardigheden, ideeën, uitwisselingen met mensen en investeringen (van hun familie). De deelnemers hadden het gevoel dat ze 'hun bedrijf zijn' waardoor ze te veel uren, tijd en energie besteden aan het werk. Deze sterke identificatie met het werk gaat ten koste van de deelname aan het gezin en het sociale leven. Dit onderzoek illustreert dat het van belang is om naar de motivatie en werkkenmerken van zelfstandig ondernemers te kijken om te begrijpen hoe zelfstandigen hun werk-privébalans ervaren. De volgende 
twee secties geven inzicht in de factoren die de ervaren werk-privébalans van zelfstandig ondernemers beïnvloeden.

\section{B. Kenmerken van het werk}

De tweede deelvraag was: 'Hoe beïnvloeden kenmerken van het werk de werkprivébalans van zelfstandig ondernemers?' Mensen kunnen kiezen voor het zelfstandig ondernemerschap vanwege de mogelijkheden en de vrijheid die het met zich meebrengt of vanwege een gebrek aan andere mogelijkheden op de arbeidsmarkt. Onderzoek op basis van de Global Entrepreneurship Monitor (2013) laat zien dat de motivatie om zelfstandig ondernemer te worden op basis van mogelijkheden positief is gerelateerd aan de tevredenheid met de balans tussen werk en leven (Annink et al., 2016c). Daarnaast wordt de werk-privébalans van zelfstandig ondernemers net als bij werknemers beïnvloed door traditionele taakeisen, zoals werkdruk, hoog aantal werkuren, 's avonds en in het weekend werken, overwerk op korte termijn, en werkonzekerheid (Prottas \& Thompson, 2006; Beutell, 2007; Tuttle \& Garr, 2009; Nordenmark et al., 2012; Davis et al., 2014; Annink et al., 2016b).

Annink et al. (2016a) laten zien dat naast traditionele werkeisen ook bedrijfskenmerken, zoals de mate van klantgerichtheid, van invloed zijn. Zelfstandigen die veel interacteren met klanten, zijn minder tevreden met hun werk-privébalans dan degenen die werkzaam zijn in industriële sectoren. Interactie met klanten wordt waarschijnlijk als stressvol ervaren ten gevolge van last-minute verwachtingen van de klant, specifieke eisen, deadlines, onregelmatige uren en werktijden die worden bepaald door klanten (Annink \& Den Dulk, 2012). Conflicten met klanten, klachten, en de noodzaak om de verwachtingen van de klant waar te maken kunnen ook worden ervaren als stressvol (Grant \& Ferris, 2012).

Het onderzoek van Annink et al. (2016a) constateert tevens dat de verschillen in de werk-privébalans van de zelfstandigen niet kunnen worden verklaard door bedrijfskenmerken zoals de mate van innovatiegerichtheid, het aantal werknemers dat men in dienst heeft en bedrijfsfase (starter/gevestigd). Werk-privébalans is blijkbaar een aandachtspunt tijdens alle stadia van het ondernemerschap (Darcy et al., 2012). De niet-significante impact van een aantal werk- en bedrijfskenmerken kan wellicht worden verklaard door de persoonlijke context van zelfstandigen. Bepaalde werk- en bedrijfskenmerken kunnen de werk-privébalans van sommige zelfstandigen bevorderen terwijl ze de werk-privébalans van anderen belemmeren. Gezien vanuit een 'Capability Approach' moeten werk- en bedrijfskenmerken eerst worden omgezet in reële hulpbronnen. Dit onderzoek benadrukt het belang van een contextuele benadering om de verschillen in werk-privébalans-ervaringen tussen de zelfstandigen te kunnen begrijpen. Hierover meer in de volgende paragraaf.

\section{Nationale context}

De derde deelvraag luidt: 'Hoe wordt de werk-privébalans van zelfstandig ondernemers gevormd door de nationale context?' Landen verschillen in de mate van overheidssteun voor de werk-privébalans van ondernemers. Met betrekking tot de beleidscontext blijkt uit tabel 1 dat zelfstandigen minder overheidssteun voor hun werk-privébalans krijgen dan werknemers, of zelfs helemaal geen. Tabel 1 
laat zien hoeveel weken werknemers en zelfstandig ondernemers voltijds betaald verlof krijgen voor zwangerschap en bevallingsverlof, vaderschaps- en ouderschapsverlof. FRE verwijst naar full-rate equivalent (FRE), welke is gedefinieerd als het aantal weken voltijds betaald verlof (OECD, 2010). Een 8 voor zwangerschapsen bevallingsverlof voor werknemers in Zweden is gebaseerd op 10 weken verlof * $80 \%$ betaling. De FRE is dan 8 . Een asterisk $\left(^{*}\right)$ achter de score betekent dat mensen verplicht zijn om dit verlof op te nemen.

Daarnaast laat deze tabel zien dat de mate van overheidssteun verschilt tussen Europese landen. Vanuit een verzorgingsstaatperspectief zijn verschillen tussen werknemers en zelfstandig ondernemers relatief klein in sociaaldemocratische landen (behalve Finland), in liberale landen en sommige voormalig socialistische landen. De verschillen zijn relatief groot in conservatieve/corporatistische verzorgingsstaten (behalve in Zwitserland, dat überhaupt weinig steun biedt) en mediterrane landen. Annink et al. (2015) concluderen dat de institutionele context een belangrijk kader schetst van waaruit werk-privébalans-ervaringen voor werknemers en zelfstandig ondernemers verklaard worden. Bij dit onderzoek moet worden opgemerkt dat de wettelijke definitie van zelfstandig ondernemerschap (en vormen van zelfstandig ondernemerschap) varieert tussen en binnen de Europese landen. Deze verschillende definities hebben gevolgen voor ondersteunende wetgeving en kan dus betekenen dat verschillende typen zelfstandig ondernemers in verschillende mate recht hebben op overheidssteun bij de werkprivébalans.

Het onderzoek van Annink et al. (2016b) op basis van de European Social Survey liet zien dat overheidssteun in de vorm van verlof en kinderopvang geen significant effect heeft op het werk-privéconflict van werknemers en zelfstandigen. Naast overheidsbeleid voor de werk-privébalans is ook gekeken naar beleid gericht op ondernemerschap. Op nationaal niveau bleek het gemak van ondernemen positief gerelateerd te zijn aan de tevredenheid met de werk-privébalans (Annink et al., 2016a). Dit impliceert dat hoe makkelijker het is om te ondernemen in een land, hoe hoger de tevredenheid met de werk-privébalans is. Bovendien heeft sociale zekerheid voor zelfstandig ondernemers in de vorm van een werkloosheidsuitkering een verzachtend effect op de relatie tussen financiële moeilijkheden en het welzijn van ondernemers (Annink et al., 2016c). De interviewstudie met zelfstandige professionals laat zien dat naast het feitelijke inkomen, hoge werkloosheid en negatieve vooruitzichten op de arbeidsmarkt ook leiden tot financiële zorgen. Vooral zorgen over het meer moeten werken voor minder inkomen heeft een negatieve invloed. Dit is in lijn met de studie van Annink et al. (2015), waaruit bleek dat werkonzekerheid een groot effect heeft op de mate van ervaren werk-privéconflict onder zelfstandigen. Zelfstandig ondernemers ervaren meer werk-gezin-conflict als ze minder interessant werk moeten doen, minder betaald krijgen, minder uren kunnen werken en minder werkzekerheid ervaren. 


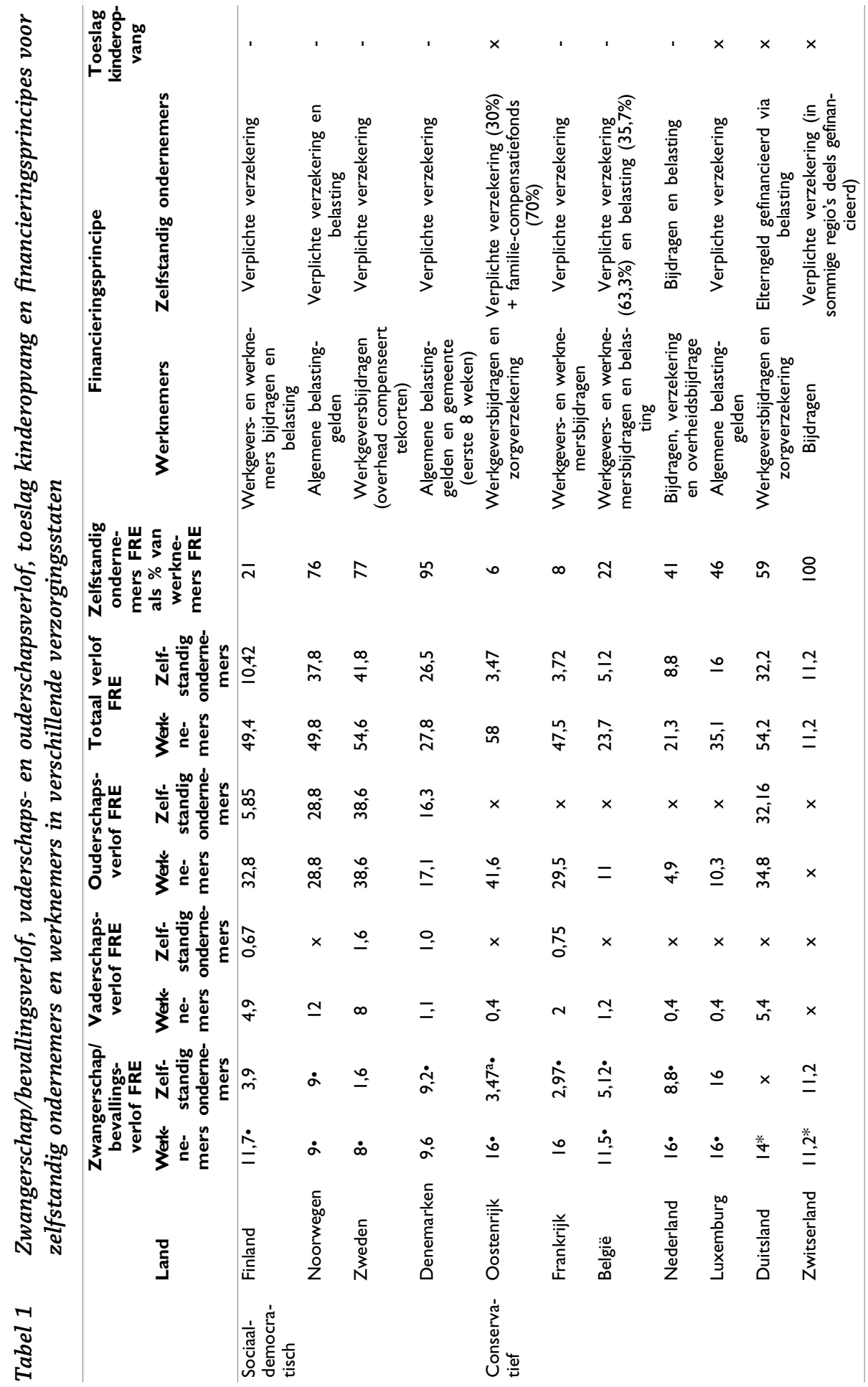




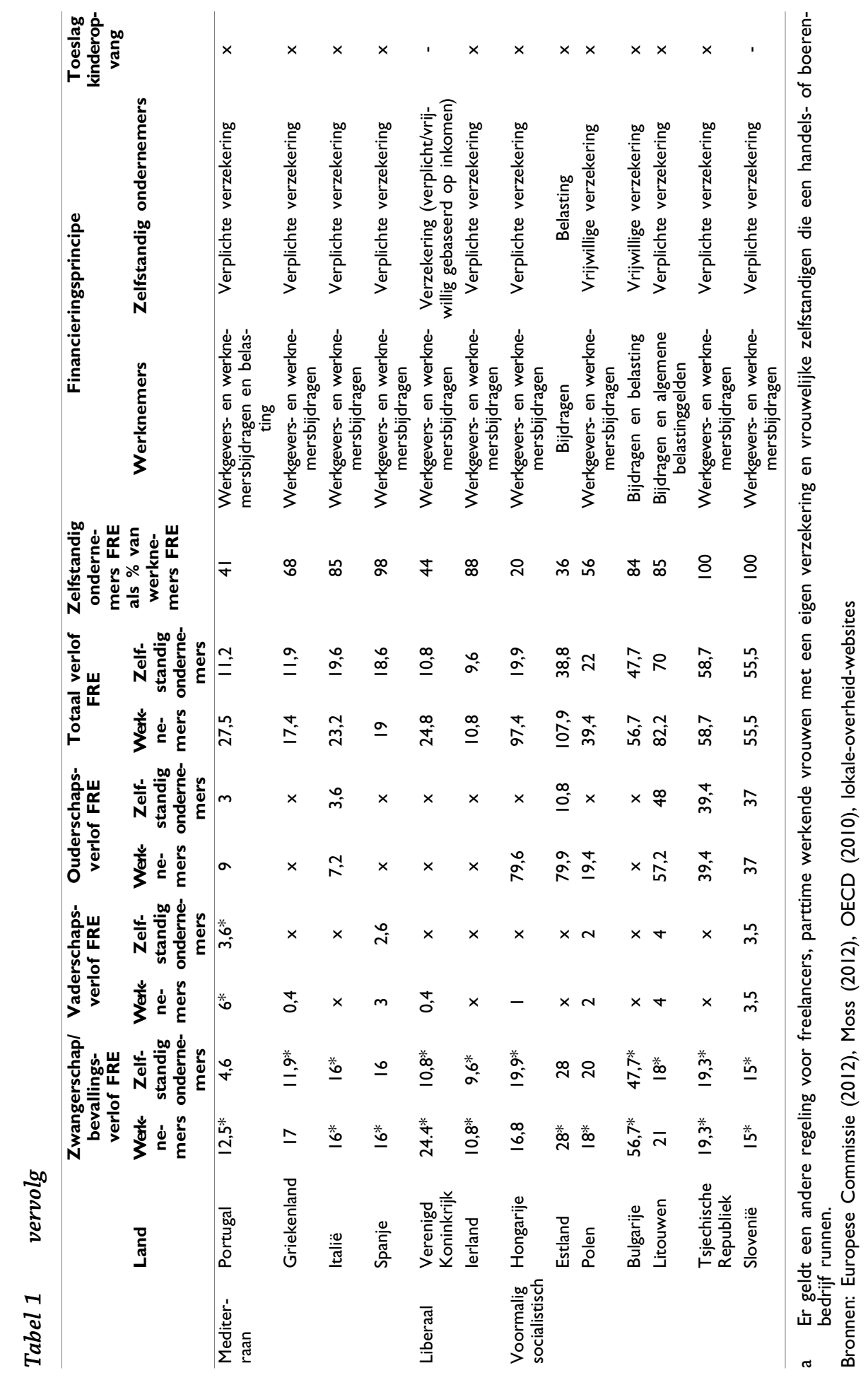


Wonen en ondernemen in een land met een hogere score op de Human Development Index is niet per definitie gunstig voor de werk-privébalans van zelfstandigen. Annink et al. (2016a) laten zien dat hoe meer mensen in staat zijn om te doen wat ze willen met hun leven, hoe lager de tevredenheid van zelfstandigen met de werk-privébalans. Dit is in lijn met het onderzoek naar de werk-privébalans van werknemers. Den Dulk en Peper (2016) concluderen dat overheidssteun het mogelijk maakt voor meer mensen om werk en gezin te combineren met als gevolg dat het aandeel tweeverdieners toeneemt. Dit vermindert echter niet noodzakelijk werk-privéconflict of tijdsdruk.

Aspecten van de culturele context die de werk-privébalans-ervaringen van zelfstandigen kunnen beïnvloeden, komen ook tot uiting in de interviewstudie onder zelfstandige professionals. Uit interviews met zelfstandige professionals blijkt dat culturele normen de sociale steun voor de werk-privébalans indirect kunnen verkleinen of vergroten. In Spanje wordt sociale steun als vanzelfsprekend gezien vanwege familiaire sociale normen. Spaanse zelfstandigen ontvangen zowel financiële als emotionele steun van hun familie. Nederlandse en Zweedse participanten ervaren dit minder. Zij hechten minder waarde aan persoonlijke relaties en halen hun steun meer uit formele netwerken. Dit laatste wordt soms als belemmering ervaren voor de werk-privébalans, vanwege de tijd en energie die het kost (Annink, 2016).

Ten slotte laat de studie van Annink et al. (2016a) zien dat in landen gekenmerkt door meer gendergelijkheid de tevredenheid met de werk-privébalans lager is onder zelfstandigen. Deze bevinding is contra-intuïtief, maar is ook zichtbaar in onderzoek onder werkenden in loondienst. Een mogelijke verklaring is dat in landen waar veel aandacht is voor de gelijkheid tussen mannen en vrouwen, de verwachtingen hoger zijn ten aanzien van een gelijke verdeling van taken en de werk-privébalans (Steiber, 2009).

De kwalitatieve studie onder zelfstandige professionals laat zien dat vrouwen veelal worstelen met het moederschapsideaal, waardoor zij het lastig vinden om een eigen bedrijf te combineren met zorgverantwoordelijkheden. Onderstaand citaat illustreert dit:

'Ik leef in een land waar de positie van vrouwen goed en gelijk is. Ik heb dezelfde rechten [als een man], maar natuurlijk zijn er ook tradities en is de moederrol heilig. Toen mijn kind net geboren was, vertelden andere vrouwen wat ik moest doen. En ze hadden het alleen tegen mij. Ik dacht: 'Hallo! Er zijn twee ouders!' Toen mijn man me hielp met ons kind zeiden ze: 'Oh, wat een goede echtgenoot zeg!' - SE8, Zweedse product designer, vrouw (33), één kind

Mannelijke zelfstandige professionals voelden zich vooral verantwoordelijk voor de inkomsten als kostwinner. Samenwonen of een huwelijk kan ertoe leiden dat zij druk ervaren van hun partner om genoeg geld te verdienen voor het huishouden, wat leidt tot meer ervaren conflict. Aan de andere kant creëert een relatie begrip en flexibiliteit om voor elkaar te zorgen, wat de werk-privébalans-mogelijkheden vergroot. 


\section{Conclusie}

De werk-privébalans blijft een belangrijk vraagstuk binnen het Nederlandse overheidsbeleid, zeker in een context waarin in toenemende mate een beroep wordt gedaan op burgers om betaald werk en zorgtaken te combineren (Yerkes \& Den Dulk, 2015). De mate waarin mensen in staat worden gesteld om betaald werk en zorgtaken te combineren, is van invloed op hun fysieke en psychische welzijn (Baxter et al., 2007; Kelly et al., 2011). Dit geldt zowel voor werkenden in loondienst als voor zelfstandig ondernemers. Opvallend is dat er weinig aandacht is voor de werk-privébalans van zelfstandigen zowel in beleid als in onderzoek. Dit terwijl met de flexibilisering van de arbeidsmarkt het aandeel zzp'ers sterk is toegenomen (Kremer et al., 2017). Deze bijdrage geeft een overzicht van wat er bekend is over de werk-privébalans van zelfstandigen in vergelijking met werkenden in loondienst en het arbeid- en zorgbeleid, gericht op deze heterogene groep.

Het besproken onderzoek geeft geen duidelijk antwoord op de vraag of zelfstandigen een betere werk-privébalans ervaren dan werkenden in loondienst. Dit komt deels door de verschillende wijzen waarop bestaand onderzoek is opgezet en de definities die worden gehanteerd. Er wordt vooralsnog weinig aandacht besteed aan de heterogeniteit van de groep zelfstandigen, terwijl onderzoek laat zien dat juist de omstandigheden waarin mensen betaald werk en andere levensdomeinen combineren, van invloed zijn op de ervaren werk-privébalans.

Zelfstandigen kenmerken zich door een sterke identificatie met werk en hechten veel belang aan autonomie en flexibiliteit, ook al leidt dit niet altijd tot het creëren van een betere balans tussen werk en privéleven. Werkonzekerheid, financiële moeilijkheden en lange werkuren kunnen leiden tot spanningen tussen levensdomeinen met stress en verminderd welzijn als gevolg. Zelfstandigen die bewust hebben gekozen voor het starten van een eigen bedrijf vanwege de kansen en mogelijkheden die het biedt, lijken beter in staat om een balans tussen werk en privé te realiseren dan mensen die noodgedwongen voor het ondernemerschap hebben gekozen. De sector waar zelfstandigen in opereren is ook van invloed, vooral veel contact met veeleisende klanten kan de tevredenheid met de werkprivébalans doen afnemen.

Overheidsbeleid in de vorm van verlof en kinderopvang lijkt geen invloed te hebben op de mate waarin zelfstandigen werk-privéconflict ervaren. Wellicht dat dit komt omdat het opnemen van verlof lastig te combineren is met de continuiteit van een onderneming, vooral voor zelfstandigen zonder personeel. Kinderopvang daarentegen stelt zelfstandigen net als werknemers in staat om zorgtaken uit te besteden. Belangrijke voorwaarde is echter dat de opvang flexibel inzetbaar is en geen financiële risico's met zich meebrengt (Yerkes \& Den Dulk, 2015). Beleidsondersteuning bij ondernemerschap en enige vorm van sociale zekerheid hebben wel een positieve invloed op de ervaren werk-privébalans. 


\section{Aanbevelingen voor toekomstig onderzoek}

Hoewel er in toenemende mate onderzoek wordt gedaan naar de werk-privébalans van zelfstandig ondernemers blijven er nog veel vragen onbeantwoord. De heterogeniteit van zelfstandigen verdient meer aandacht, onder andere door het definiëren van specifieke taakeisen en hulpbronnen voor zelfstandig ondernemers. Een andere aanbeveling is het erkennen van het belang van individuele keuze en de motivatie van zelfstandigen om een eigen bedrijf te starten. Een genderperspectief zou kunnen duiden hoe culturele verwachtingen de ervaren werkprivébalans van mannelijke en vrouwelijke zelfstandig ondernemers beïnvloedt. Van belang is om een contextuele benadering te hanteren. Daarmee wordt het mogelijk om ook de ervaringen van zelfstandig ondernemers in verschillende sectoren en landen te begrijpen.

Met betrekking tot onderzoeksmethodologie zouden wetenschappers aandacht kunnen besteden aan de conceptualisering en de meting van werk-privébalans, autonomie en sociale steun. Multi-level analyse is een geschikte methode om de invloed van nationale contextfactoren op de werk-privébalans in kaart te brengen. Om de kwaliteit van dataverzameling door middel van enquêtes te verbeteren is het advies om ook kenmerken van het werk en het bedrijf te verzamelen en het aantal indicatoren op land-niveau uit te breiden. Longitudinale paneldata zijn nodig om de individuele keuzes, relationele aspecten en de invloed van veranderingen in de context op werk-privébalans beter te begrijpen. Kwalitatieveinterviewmethoden kunnen de mechanismen die van invloed zijn op de werkprivébalans van zelfstandigen in verschillende contexten beschrijven. Ten slotte kan toepassing van Qualitative Comparative Analysis (QCA) de verschillende combinaties van causale condities die leiden tot werk-privébalans, in kaart brengen.

\section{Praktische aanbevelingen}

Deze paragraaf biedt praktische aanbevelingen voor beleidsmakers op nationaal en lokaal niveau, naasten van zelfstandig ondernemers en zelfstandig ondernemers zelf.

Huidige onderzoeksbevindingen suggereren dat het van belang is dat beleid zich ook richt op het domein van betaald werk en niet alleen op ondersteuning bij zorgtaken in de vorm van verlofregelingen en kinderopvang. Onderzoek laat zien dat werkeisen eerder conflicteren met het privéleven dan vice versa. Steun voor ondernemerschap kan daarom eerder effectief zijn dan meer aandacht voor werk-privébeleid omdat dit de taakeisen die voortvloeien vanuit het werk als zelfstandige vermindert, waardoor er meer tijd en energie overblijven voor andere levensdomeinen. Ten eerste kunnen nationale overheden het ondernemen in hun land makkelijker maken. Beleidsmakers kunnen denken aan het vereenvoudigen van het starten van een bedrijf, omgaan met bouwvergunningen, het regelen van elektriciteit, het registreren van eigendom, het verkrijgen van krediet, de bescherming van minderheidsaandeelhouders, het betalen van belastingen, 
de handel over de grenzen heen, handhaving van contracten, en het oplossen van insolventie (World Bank Database, 2014).

Daarnaast kunnen beleidsmakers op nationaal niveau het verlofbeleid herzien en de mogelijkheden voor flexibele en betaalbare kinderopvang vergroten.

Lokale overheden kunnen in de ontwikkeling van nieuw beleid rekening houden met de variatie in typen zelfstandig ondernemers. Daarnaast is het belangrijk dat lokale overheden aan zelfstandig ondernemers laten merken dat ze hen begrijpen en vertrouwen. Het verstrekken van leningen en het aanbieden van trainingen die aandacht hebben voor het realiseren van een werk-privébalans zijn twee manieren om zelfstandig ondernemers te ondersteunen bij de combinatie van ondernemerschap en andere levensdomeinen en verantwoordelijkheden.

Mensen in de naaste omgeving van zelfstandig ondernemers kunnen emotionele en praktische steun bieden voor de werk-privébalans. Daarbij is het van belang om niet (constant) twijfels te uiten over de levensvatbaarheid van de onderneming.

Zelfstandig ondernemers kunnen zelf hun bewustzijn en begrip van eigen welzijn en werk-privébalans vergroten. Daarnaast kunnen zij reflecteren op hun werkomstandigheden en motivatie om zelfstandig ondernemer te zijn. Indien nodig kunnen zij hun werkomstandigheden herzien of besluiten om in loondienst te gaan werken. Daarnaast zouden zelfstandig ondernemers zich moeten realiseren welke praktische en emotionele sociale steun aanwezig is binnen hun netwerk en deze vervolgens benutten. Tezamen kunnen de genoemde inspanningen leiden tot minder stress, spanningen en meer balans en welzijn, in en rondom het bedrijf.

\section{Literatuur}

Allen, T.D., Herst, D.E., Bruck, C.S., \& Sutton, M. (2000). Consequences associated with work-to-family conflict: A review and agenda for future research. Journal of Occupational Health Psychology, 5(2), 278-308.

Annink, A. (2016). From social support to capabilities for the work-life balance of independent professionals. Journal of Management and Organization. doi: https://doi.org/ 10.1017/jmo.2016.53

Annink, A. (2017). Busyness around the Business. A cross-national comparative study of the work-life balance of self-employed workers. Rotterdam: Erasmus University Rotterdam.

Annink, A., \& Den Dulk, L. (2012). Autonomy: the panacea for self-employed women's werk-privé balans? Community, Work \& Family, 15(4), 383-402.

Annink, A., Den Dulk, L., \& Steijn, B. (2015). Work-family state support for the selfemployed across Europe. Journal of Entrepreneurship and Public Policy, 4(2), 187-208.

Annink, A., Den Dulk, L., \& Amorós, J.E. (2016a). Different strokes for different folks? The impact of heterogeneity in work characteristics and country contexts on worklife balance among the self-employed. International Journal of Entrepreneurial Behavior \& Research, 22(6), 880-902.

Annink, A., Den Dulk, L., \& Steijn, B. (2016b). Work-family conflict among employees and the self-employed across Europe. Social Indicators Research, 126(2), 571-593. 
Annink, A., Gorgievski, M., \& Den Dulk, L. (2016c). Financial hardship and well-being: A cross-national comparison among the European self-employed. European Journal of Work and Organizational Psychology, 1-13.

Bakker, A.B., \& Demerouti, E. (2007). The job demands-resources model: State of the art. Journal of Managerial Psychology, 22(3), 309-328.

Baxter, J., Gray, M., Alexander, M., Strazdins, L., \& Bittman, M. (2007). Mothers and fathers with young children: Paid employment, caring and wellbeing. Australian Department of Families, Community Services and Indigenous Affairs: Canberra, Australia.

Beutell, N.J. (2007) Self-employment, work-family conflict and work-family synergy: Antecedents and consequences. Journal of Small Business and Entrepreneurship, 20(4), 325-334.

Bianchi, S. M., \& Milkie, M. A. (2010). Work and family research in the first decade of the 21st century. Journal of Marriage and Family, 72(3), 705-725.

Bunk, J.A., Dugan, A.G., D’Agostino, A.L., \& Barnes-Farrell, J.L. (2012). Understanding work-to-family conflict among self-employed workers: Utilising a cognitive appraisal framework. Journal of Entrepreneurship, 21(2), 223-251.

Casale, G. (2011). The employment relationship: A comparative overview. International Labour Organization. Oxford: Hart Publishing.

Darcy, C., McCarthy, A., Hill, J., \& Grady, G. (2012). Work-life balance: One size fits all? An exploratory analysis of the differential effects of career stage. European Management Journal, 30(2), 111-120.

Davis, S.N., Shevchuk, A., \& Strebkov, D. (2014). Pathways to satisfaction withwork-life balance: The case of Russian-language internet freelancers. Journal of Family and Economic Issues, 35(4), 542-556.

Demerouti, E., Bakker, A.B., Nachreiner, F., \& Schaufeli, W.B. (2001). The job demandsresources model of burnout. Journal of Applied Psychology, 86(3), 499-512.

Den Dulk L., \& Peper, B. (2009)Managing work-life policies in the European workplace: explorations for future research. Working Paper on the Reconciliation of Work and Welfare in Europe 04/2009 RECWOWE: Edinburgh.

Den Dulk, L. \& Peper, B. (2016). The impact of national policies on work-family experiences. In T.D. Allen \& L.T. Eby (Eds.), The Oxford Handbook of Work and Family (pp. 300-314). Oxford University Press: Oxford.

Den Dulk, L., Bäck-Wiklund, M., Lewis, S., \& Redai, D. (2011).Quality of life and work in a changing Europe: A theoretical framework. In M. Bäck-Wiklund, T. van der Lippe, L. den Dulk \& A. van Doorne-Huiskes (Eds.), Quality of life and work in Europe: theory, practice and policy (pp. 17-31). Palgrave Macmillan.

Den Dulk, L., Peper, A., Kanjuo-Mrčela, A., \& Ignjatović, M. (2016). Supervisory support in Slovenian and Dutch organizations: A contextualizing approach. Community, Work and Family, 19(2), 193-212.

Duncan, K., \& Pettigrew, R. (2012) . The effect of work arrangements on perception of work-family balance. Community, Work and Family, 15(4), 403-423

European Commission. (2012). Employment, social affairs and inclusion: Social protection systems - MISSOC. Available at: http://ec.europa.eu/employment_social/missoc/db/ public/ compareTables.do;jsessionid $1 / 4$ ByhkQWpL2TB9BQzglhn1KLbLyJ7xGLMhZ29X4p17Jw7 kqP8m22h0!382011170?year $1 / 420120101$ andlang $1 / 4$ e

European Social Survey. (2004). ESS2 Data download. Available at: http://www.europeansocialsurvey.org/data/download.html?r=2

European Social Survey. (2010). ESS5 Data download. Available at: http://www.europeansocialsurvey.org/data/download.html?r=5

Frone, M.R. (2003). Work-Family Balance. In J.C. Quick \& L.E. Tetrick (Eds.), Handbook of occupational health psychology (pp. 143-162). Washington: American Psychological Association.

Gimenez-Nadal, J.I., \& Sevilla, A. (2012). Trends in time allocation: A cross-country analysis. European Economic Review, 56(6), 1338-1359.

GEM. (2013). Global Entrepreneurship Monitor data. Available at: http://gemconsortium.org/ data 
Gorgievski, M.J., Bakker, A.B., Schaufeli, W.B., Veen, H.B., \& Giesen, C.W. (2010b). Financial problems and psychological distress: Investigating reciprocal effects among business owners. Journal of Occupational and Organizational Psychology, 83(2), 513530 .

Grant, S., \& Ferris, K. (2012). Identifying sources of occupational stress in entrepreneurs for measurement. International Journal of Entrepreneurial Venturing, 4(4), 1-21.

Guest, D.E. (2002). Perspectives on the study of work-life balance. Social Science Information, 41(2), 255-279.

Greenhaus, J.H., \& Beutell, N.J. (1985). Sources of conflict between work and family roles. Academy of Management Review, 10(1), 76-88.

Grzywacz, J. G., \& Marks, N. F. (2000). Reconceptualizing the work-family interface: An ecological perspective on the correlates of positive and negative spillover between work and family. Journal of occupational health psychology, 5(1), 111-126.

Hobfoll, S.E. (1989). Conservation of resources: A new attempt at conceptualizing stress. American Psychologist, 44(3), 513.

Hobfoll, S.E. (2001). The influence of culture, community, and the nested-self in the stress process: Advancing conservation of resources theory. Applied Psychology, 50(3), 337-421.

Hobson, B. (2011). The agency gap in work-life balance: Applying Sen's capabilities framework within European contexts. Social Politics: International Studies in Gender, State \& Society, 18(2), 147-167.

Jamal, M. (2009). Self-employment and quality of work and nonwork life: A study in cross-cultural management. Journal of Small Business and Entrepreneurship, 22(4), 455466.

Johansson Sevä, I., \& Öun, I. (2015). Self-employment as a strategy for dealing with the competing demands of work and family? The importance of family/lifestyle motives. Gender, Work \& Organization, 22(3), 256-272.

Kelly, E. L., Moen, P., \& Tranby, E. (2011). Changing Workplaces to Reduce Work-Family Conflict: Schedule Control in a White-Collar Organization. American Sociological Review, 76(2), 265-290.

König, S., \& Cesinger, B. (2015). Gendered work-family conflict in Germany: do selfemployment and flexibility matter?. Work, employment and society, 29(4), 531-549.

Kremer, M., Went, R. en Knottnerus, A. (red.) (2017). Voor de zekerheid. De toekomst van flexibel werkenden en de moderne organisatie van arbeid (WRR-verkenning $\mathrm{nr} 36$ ). Den Haag: WRR.

Leighton, P., \& Brown, D. (2013). Future working: The rise of Europe's independent professionals. London: PCG.

Lewis, S., Brannen, J., \& Nilsen, A. (2009). Work, families and organisations in transition: European perspectives. Bristol: Policy Press.

Li, Y., Miao, L., Zhao, X., \& Lehto, X. (2013). When family rooms become guest lounges: Work-family balance of B\&B innkeepers. International Journal of Hospitality Management, 34, 138-149.

McKeown, T. (2015). What's in a name? The value of 'entrepreneurs' compared to 'selfemployed'... But what about 'freelancing' or 'ipro'? In A. Burke (Ed.), The handbook of research on freelancing and self-employment (pp. 121-134). Dublin: State Hall Academic Publishing.

Moss, P. (2012). International review of leave policies and related research 2012. London: International Network on Leave Policies and Research, Institute of Education.

Nordenmark, M., Vinberg, S., \& Strandh, M. (2012). Job control and demands, work-life balance and wellbeing among self-employed men and women in Europe. Society, Health \& Vulnerability, 3.

OECD. (2010). Additional leave entitlements for working parents. OECD, social policy division, directorate of employment, labour and social affairs. Verkregen via: http://www.oecd.org/ els/soc/PF2_3_Additional_leave_entitlements_of_working_parents.pdf

OECD (2011). Doing better for families. Chapter 1: Families are changing. Verkregen via: http://www.oecd.org/els/soc/47701118.pdf

Parasuraman, S., \& Simmers, C.A. (2001). Type of employment, work-family conflict and well-being: A comparative study. Journal of Organizational Behavior, 22(5), 551-568. 
Prottas, D.J., \& Thompson, C.A. (2006). Stress, satisfaction, and the work-family interface: A comparison of self-employed business owners, independents, and organizational employees. Journal of Occupational Health Psychology, 11(4), 366.

Schaufeli, W.B., \& Taris, T.W. (2014). A critical review of the Job Demands-Resources Model: Implications for improving work and health. In G. Bauer \& O. Hammig (Eds.), Bridging occupational, organizational and public health (pp. 43-68). Dordrecht: Springer Netherlands.

Schieman, S., \& Young, M. (2015). Who engages in work-family multitasking? A study of Canadian and American workers. Social Indicators Research, 120(3), 741-767.

Sen, A. (1985). Well-being, agency and freedom: the Dewey lectures 1984. The Journal of Philosophy, 82(4), 169-221.

Shelton, L.M. (2006). Female entrepreneurs, work-family conflict, and venture performance: New insights into the work-family interface. Journal of Small Business Management, 44(2), 285-297.

Steiber, N. (2009). Reported levels of time-based and strain-based conflict between work and family roles in Europe: A multilevel approach. Social Indicators Research, 93(3), 469-488.

Stephan, U., \& Roesler, U. (2010). Health of entrepreneurs versus employees in a national representative sample. Journal of Occupational and Organizational Psychology, 83(3), 717-738.

Taris, T.W., Geurts, S.A.E., Kompier, M.A.J., Lagerveld, S., \& Blonk, R.W.B. (2008). My love, my life, my everything: Work-home interaction among self-employed. In K. Naswall (Ed.), The individual in the changing working life (pp. 147-168). Cambridge: Cambridge University Press.

Tremblay, D. G., \& Genin, E. (2008). Money, work-life balance and autonomy: why do IT professionals choose self-employment?. Applied research in quality of life, 3(3), 161179.

Tuttle, R., \& Garr, M. (2009). Self-employment, work-family fit and mental health among female workers. Journal of family and economic issues, 30(3), 282-292.

Valcour, M. (2007). Work-based resources as moderators of the relationship between work hours and satisfaction with work-family balance. Journal of Applied Psychology, 92(6), 1512.

Voydanoff, P. (2005). Toward a conceptualization of perceived work-family fit and balance: A demands and resources approach. Journal of Marriage and Family, 67(4), 822-836.

Williams, D.R. (2004). Effects of childcare activities on the duration of self-employment in Europe. Entrepreneurship Theory and Practice, 28(5), 467-485.

Wood, S. J., \& Michaelides, G. (2015). Challenge and hindrance stressors and wellbeingbased work-nonwork interference: A diary study of portfolio workers. Human relations, doi: 10.1177/0018726715580866

World Bank Database. (2014). The ease of doing business. Available at: www.data.worldbank.org

Yerkes, M.A., \& Dulk, L. den (2015). Arbeid-en-zorgbeleid in de participatiesamenleving: Een vergroting van de mogelijkheden? Tijdschrift voor Arbeidsvraagstukken, 31(4), 510528. 